\title{
Vertical profiles of virus-like particles and bacteria in the water column and sediments of Chesapeake Bay, USA
}

\author{
Lisa A. Drake ${ }^{1, *}$, Keun-Hyung Choi ${ }^{1}$, A. G. Edward Haskell ${ }^{2}$, Fred C. Dobbs ${ }^{1}$ \\ ${ }^{1}$ Department of Ocean, Earth and Atmospheric Sciences, Old Dominion University, 4600 Elkhorn Avenue, \\ Norfolk, Virginia 23529, USA \\ ${ }^{2}$ Center for Coastal Physical Oceanography, Department of Ocean, Earth and Atmospheric Sciences, \\ Old Dominion University, 768 West $52^{\text {nd }}$ Street, Norfolk Virginia 23529, USA
}

\begin{abstract}
Vertical profiles of virus-like particles (VLPs) and bacteria were determined by near-synoptic sampling through the water column and 15 to $25 \mathrm{~cm}$ into the sediment at 5 stations across the mouth of Chesapeake Bay, USA. VLPs were about 10 times more abundant in the pore water (grand mean $=3.6 \times 10^{8}$ VLPS $\mathrm{ml}^{-1}$ ) than in the water column (grand mean $=3.8 \times 10^{7} \mathrm{VLPs} \mathrm{m}^{-1}$ ). Similarly, bacteria counts were about 3 times higher in the pore water (grand mean $=6.5 \times 10^{6}$ bacteria $\mathrm{ml}^{-1}$ ) than in the water column (grand mean $=2.4 \times 10^{6}$ bacteria $\mathrm{ml}^{-1}$ ). The virus to bacteria ratio (VBR) was greater in the pore water (range $=29$ to 85 ) than in the water column (range $=12$ to 17). The VBR was lowest in the water-over-boxcore samples and variable in the pore water. Counts of VLPs and bacteria were positively correlated in the water column, although neither was correlated to chlorophyll $a$. In the water column, VLP and bacteria counts exhibited significant differences among stations, with the highest values on the southern side of the Bay mouth. In the pore water, VLP abundance varied with depth and was negatively correlated to grain size. Bacteria abundance was highest at the sediment-water interface, decreased in the first $\mathrm{cm}$ of sediment, was uniform in the deeper horizons, and showed no significant relationship with grain size. Bacteria counts in pore water were not significantly different among stations. In contrast, VLP abundances in pore water were significantly different among stations, although they did not increase in abundance from north to south across the Bay mouth, as did counts of water-column VLPs. These are the first data indicating the abundance of VLPs below the surface layer of sediment in aquatic systems and demonstrate that VLPS are components of the sedimentary microbial community to at least $25 \mathrm{~cm}$ depth.
\end{abstract}

KEY WORDS: Virus abundance - VLP - Sediment pore water - Yo-Pro - Chesapeake Bay

\section{INTRODUCTION}

Although the existence of aquatic viruses has been known for decades (Spencer 1955, Valentine et al. 1966, Torrella \& Morita 1979), their prominence as functional members of aquatic microbial communities first was hypothesized when high numbers, on the order of $10^{4}$ to $10^{8}$ viruses and virus-like particles (VLPs) $\mathrm{ml}^{-1}$, were counted in fresh- and saltwater environments (e.g. Bergh et al. 1989, Paul et al. 1993, Hara et

=E-mail: ldrake@odu.edu al. 1996, Proctor 1997). Subsequent field and laboratory experiments demonstrated that viruses can control aquatic microbial populations at various trophic levels. Within the microbial food web, for example, bacteria can be killed by viruses at a rate equal to or greater than mortality caused by the agents thought to be their primary grazers, heterotrophic protozoans (Proctor \& Fuhrman 1990, Fuhrman \& Noble 1995, Weinbauer et al. 1995). Furthermore, up to $62 \%$ of the mortality of free-living marine bacteria and $52 \%$ of particle-associated marine bacteria may be attributable to viruses (Proctor et al. 1993), with an average of $20 \%$ of marine heterotrophic bacteria infected (Suttle 1994). 
Given the potential for viruses to control marine and freshwater microbial communities (Mathias et al. 1995. Middelboe et al. 1996) and, therefore, production of dissolved organic matter and nutrient cycling, viral infection has been incorporated into models of marine pelagic microbial food webs (Bratbak et al. 1992, Fuhrman 1992, Murray \& Eldridge 1994). Yet, little is known about the abundance, distribution, and functional role of viruses in sediments. There are only a few reports concerning naturally occurring benthic viruses, all of which have demonstrated viruses to be more abundant in surface sediment and pore water than in the overlying water. Viruses were 10 to 1000 times more abundant in the top $1 \mathrm{~cm}$ of sediment in Lac Gilbert, Canada, than in the water column (Maranger \& Bird 1996). Similarly, viral counts in surface sediments in Key Largo and Tampa Bay, USA, were almost 100 to 1000 times greater than counts from the water column (Paul et al. 1993). Viruses in pore water squeezed from the uppermost $\mathrm{cm}$ of sediment from the Chukchi Sea were about 9 times more abundant than viruses in the surface water (Steward et al. 1996).

There has been only 1 report of VLPs in pore water (Steward et al. 1996) and no reports of viruses below the surface horizon of the sediment. To ascertain whether there exists a significant VLP pool in pore water of the lower Chesapeake Bay (USA), we took preliminary samples from a single site in February 1996 (Drake et al. 1997). We found VLP concentrations of $10^{8} \mathrm{ml}^{-1}$ in sediment horizons extending to $8 \mathrm{~cm}$, and we subsequently designed and carried out a more geographically extensive sampling of lower Chesapeake Bay sediments. In this paper, we present vertical profiles of VLPs and bacteria at the mouth of Chesapeake Bay, profiles that extend from surface waters, through the water column, and into the sediment. We use these data to infer possible functional roles of VLPs in the sediment communities of coastal areas.

\section{MATERIALS AND METHODS}

Study site. Samples were collected on 4 March 1997 during the spring phytoplankton bloom (Dobbs et al unpubl. data), at 5 stations along a transect across the mouth of the Chesapeake Bay (Fig. 1).

Water-column samples. An SBE25 CTD (Sea-Bird Electronics, Inc., Bellevue, Washington) was used to determine vertical profiles of water temperature, salinity, and density. A submersible pump was used to collect water samples from the surface, mid-depth, and $1 \mathrm{~m}$ above the bottom at each station. The pump was flushed for $1 \mathrm{~min}$ at each depth before 3 independent, triplicate samples were taken for direct counts of VLPs, direct counts of bacteria, and for determination of

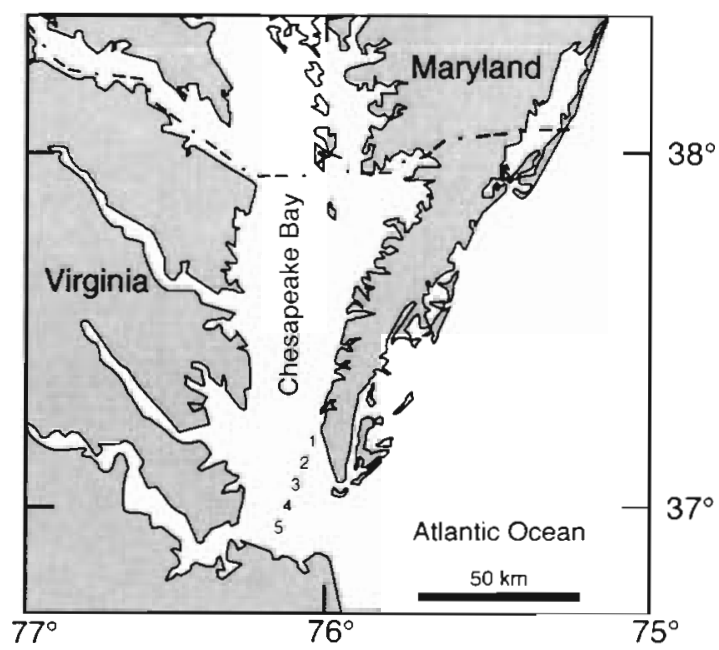

Fig. 1. Map of lower Chesapeake Bay, USA. Location of sampling stations are indicated by numbers

chlorophyll a (chl a) concentrations. For VLP counts, approximately $1 \mathrm{ml}$ of seawater was poured into sterile microfuge tubes. For bacteria counts, $10 \mathrm{ml}$ of seawater was transferred to glass vials containing $750 \mu \mathrm{l}$ of filtered $(0.2 \mu \mathrm{m})$ formalin $(2.6 \%$ final concentration of formaldehyde). Chlorophyll a samples were taken by filtering $100 \mathrm{ml}$ of seawater onto $47 \mathrm{~mm}$ diameter glass fiber filters (GF/F Whatman) at a vacuum pressure of $150 \mathrm{~mm} \mathrm{Hg}$

Box-coring device. A spade-type box-coring device with a rectangular core $(10.5 \times 17.5 \times 35 \mathrm{~cm})$ was used to collect sediment with a minimum of disturbance. The device had a hinged cutting arm that sealed the sample in situ.

Sediment pore-water samples. At each station, the boxcore was deployed 3 times; thus, 3 independent, replicate sediment samples were collected from each sediment horizon at each station for analysis of VLP and bacteria abundances in pore water. The vertical profile of sediment collected by the boxcore was exposed, and samples were removed from 6 horizons: sediment-water interface, $0-1,1-2,2-3$, and 3-4 cm, and deep ( $1 \mathrm{~cm}$ sample between 11 and $27 \mathrm{~cm}$ depending on the depth of the core) (depths are relative to the sediment-water interface). Samples of sediment for VLP and bacteria counts in pore water were collected in sterile $15 \mathrm{ml}$ disposable centrifuge tubes. Samples for determining sediment characteristics were collected in glass vials. Sediment samples for VLP and bacteria counts in pore water were centrifuged upon return to the laboratory in a Damon/IEC Division HN$S$ centrifuge for 10 to $50 \mathrm{~min}$ at ca $745 \times \mathrm{g}$ to express pore water. In some cases, the amount of pore water extracted was sufficient only for single or duplicate samples. Water-column and sediment pore-water sam- 
ples for VLP counts were diluted $2 \times$ and $100 \times$, respectively, with $0.02 \mu \mathrm{m}$-filtered distilled, deionized water. Pore-water samples for bacteria direct counts were fixed with filtered $(0.2 \mu \mathrm{m})$ formalin $(2.6 \%$ final concentration of formaldehyde).

VLP enumeration and counting accuracy. VLPS were counted using the method of Hennes \& Suttle (1995). Briefly, upon return to the laboratory, unfixed water-column and sediment pore-water samples were diluted with $0.02 \mu \mathrm{m}$-filtered distilled, deionized water. Next, diluted samples were filtered onto $0.02 \mu \mathrm{m}$-pore size Anodisc ${ }^{\mathrm{TM}}$ filters (Whatman International Ltd, Maidstone, England) and stained in the dark for $2 \mathrm{~d}$ at room temperature with a cyanide-based working solution of the nucleic acid stain Yo-ProTM-1 iodide (491/509) \{Quinolinium, 4-[(3-methy]-2(3H)-benzoxazolylidene)methyl]-1-[3-(trimethylammonio)propyl]diiodide) (Molecular Probes, Inc., Eugene, Oregon). Filters were rinsed twice with $0.02 \mu \mathrm{m}$-filtered distilled, deionized water, placed on microscope slides, and stored in the dark at $-85^{\circ} \mathrm{C}$ until they were randomly chosen (in groups of 2), thawed in the dark at room temperature for ca $5 \mathrm{~min}$, and VLPs were counted using an Olympus BX50 System Microscope with a BX-FLA epifluorescence attachment.

VLP controls and counting accuracy. Five control filters were prepared using only $0.02 \mu \mathrm{m}$-filtered distilled, deionized water and their average VLP count was subtracted from values determined in field samples. In order to determine the number of microscopic fields necessary to estimate accurately the number of VLPs on a filter, a running variance:running mean ratio was calculated from VLP counts of pore water collected at Stn 3.

Efficiency of VLP extraction from pore water. A known concentration of coliphage $\mathrm{T} 2$ in $0.85 \%$ saline was added to archived sediment from the study site by mixing the sediment-coliphage mixture on a medium setting for $10 \mathrm{~s}$ using a Fisher Vortex-Genie ${ }^{\mathrm{TM}}$. Pore water was expressed by centrifuging samples for $10 \mathrm{~min}$ at $634 \times g$, and VLPs were counted as described above. Extraction efficiency was determined by dividing VLP counts in coliphage-amended pore water ( $\mathrm{n}=$ 4) by the sum of counts in un-amended pore water ( $n=$ 3 ) plus counts of the known concentration of coliphage $(\mathrm{n}=4)$.

VLPs versus dissolved DNA. It is conceivable that dissolved DNA within water samples could bind to YoPro $^{\mathrm{TM}}-1$ and thereby inflate estimates of VLP abundance. Hennes \& Suttle (1995) demonstrated this scenario is unlikely to occur with water-column samples. However, it was appropriate to test this possibility using pore water given that sediments contain high numbers of bacteria (Rublee 1982), a potential source of dissolved DNA.
VLP counts were compared between pore-water samples treated with the DNA-degrading enzyme Deoxyribonuclease I (DNase I) and controls. 250 Kunitz units of DNase I (Type II, from bovine pancreas, Sigma Chemical Company, St. Louis, MO, D-4527) in $25 \mu$ of $0.15 \mathrm{M} \mathrm{NaCl}$ was added to a $1 \mathrm{ml}$ sample of pore water and incubated at room temperature for 30 min (Suttle 1993, Hennes \& Suttle 1995). This amount

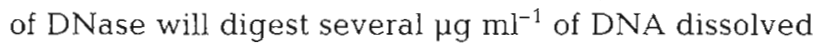
in seawater (Hennes \& Suttle 1995). To a $1 \mathrm{ml}$ control sample of pore water, $25 \mu \mathrm{l}$ of $0.15 \mathrm{M} \mathrm{NaCl}$ was added, and the sample was also incubated. Next, both the control and experimental samples were diluted $100 \times, 4$ subsamples were removed from each, and VLPs were enumerated.

To confirm the DNase digested DNA in seawater, its activity was assayed. 250 Kunitz units of DNase was added to $35 \mathrm{\mu g} \mathrm{ml}^{-1}$ of DNA (Type I, 'highly polymerized' from calf thymus, Sigma Chemical Company, D-1501) in seawater (salinity $=20$, representative of pore water at Stns 1-5), and the temporal change in absorbance at $260 \mathrm{~nm}$ was monitored using a Shimadzu UV-visible recording spectrophotometer UV160U.

Bacteria enumeration. Formalin-fixed samples were stored in the dark at $4^{\circ} \mathrm{C}$ for 1 wk until they were filtered onto $0.2 \mu \mathrm{m}$ black polycarbonate filters (Poretics, Livermore, California) and stained with the nucleic acid stain DAPI (4',6-diamidino-2-phenylindole) (final concentration of $1 \mu \mathrm{g} \mathrm{ml}^{-1}$ ) (Sigma Chemical Company) (Porter \& Feig 1980). Filters were stored in the dark at $-85^{\circ} \mathrm{C}$ for 2 mo until the bacteria were counted using epifluorescence microscopy (see above).

Chl a determination. Filters were wrapped in foil and stored at $-85^{\circ} \mathrm{C}$ until they were homogenized, and chl a was extracted in acetone and measured fluorometrically (Parsons et al. 1992).

Sediment characteristics. Sediment from the study site was analyzed to determine its particle size, water content, and combustible fraction. To determine particle-size distribution, samples from the $0-1 \mathrm{~cm}$ horizon and deep horizon ( $\mathrm{n}=3$ per horizon) were wet-sieved through a series of nested sieves $(1000,500,250,125$, and $63 \mu \mathrm{m}$ ) using distilled water. The fraction $<63 \mu \mathrm{m}$ was collected by vacuum filtration on dried filters (Whatman GF/F). All fractions were placed into tared aluminum dishes and dried to constant mass at $60^{\circ} \mathrm{C}$. Mean grain size was calculated as Folk's $M_{z 50}$ (Folk 1980). To determine water content, whole sediment samples from all 6 horizons ( $\mathrm{n}=3$ per horizon) were weighed, then dried to constant mass at $60^{\circ} \mathrm{C}$. To determine the combustible fraction, a surrogate measure of organic content, samples from all horizons ( $\mathrm{n}=$ 3 per horizon) were placed in tared aluminum dishes, dried overnight at $60^{\circ} \mathrm{C}$, combusted for $4 \mathrm{~h}$ at $450^{\circ} \mathrm{C}$, 

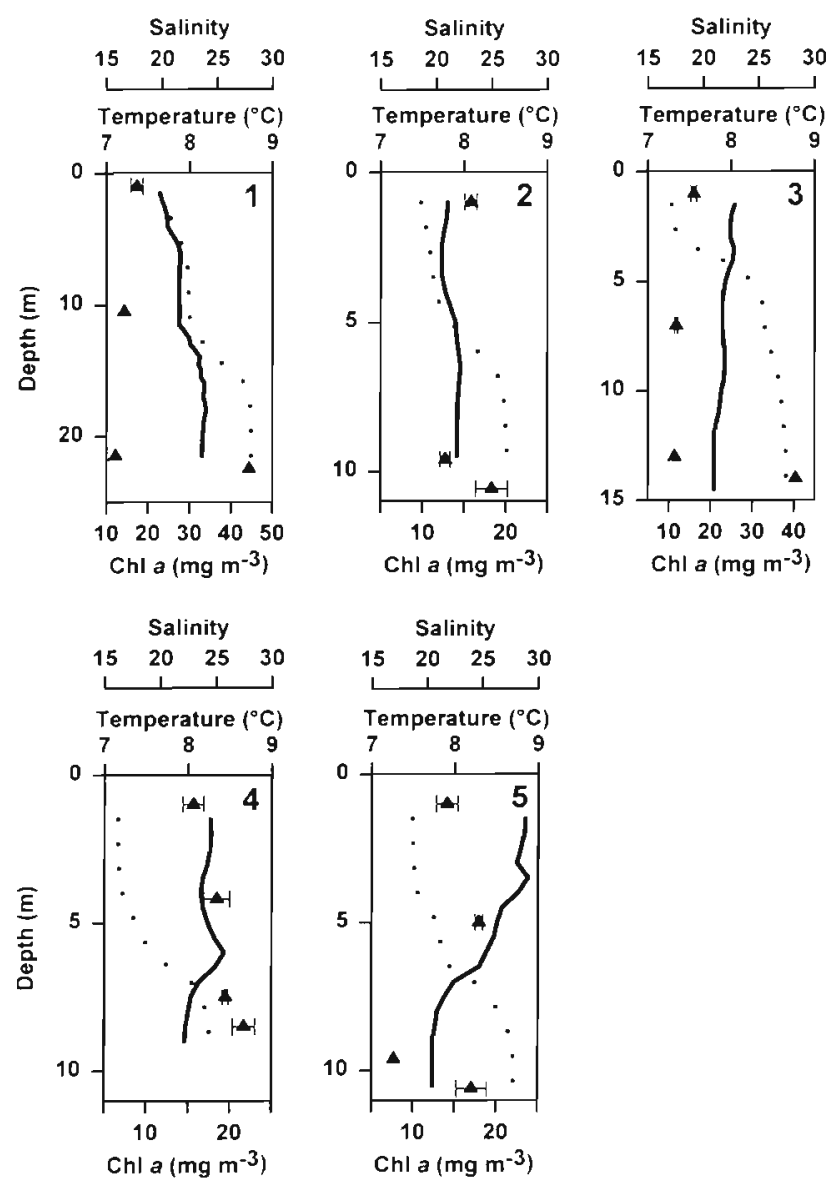

Fig. 2. Water-column profiles of temperature (-), salinity $(\cdot)$, and chl a (4) at Stns 1 to 5 . Chl a data are mean values $(\mathrm{n}=2$ or 3 ) $\pm 1 \mathrm{SE}$ (for data with $\mathrm{n}=3$ ), with data points at the deepest depths representing samples from the water over the box core

cooled in a desiccator, and weighed again to determine the mass difference following combustion.

Data analysis. Data were analyzed using SAS version 6.09 (SAS 1996).

\section{RESULTS}

\section{Hydrographic data}

The water column was strongly stratified at all stations across the mouth of the bay, based on changes of temperature and salinity with depth (Fig. 2). Water temperature ranged from 7.6 (Stn 1, surface) to $8.9^{\circ} \mathrm{C}$ (Stn 5, mid-depth), and salinity ranged from 16.2 (Stn 4 , surface) to 28.0 (Stn 1, bottom). Density profiles (sigma-t) were forced by salinity at Stns 1 to 3 and by both temperature and salinity at Stns 4 and 5. Average chl a values in water-column samples ranged from 7.7 (Stn 5, bottom) to $19.5 \mathrm{mg} \mathrm{m}^{-3}$ (Stn 4, bot- tom). A consistent pattern among stations was an increase in the average chl a concentrations in the water over the core (WOC) samples relative to the deepest water-column samples (Fig. 2). The increase was most likely an artifact of sampling due to the resuspension of algae at the sediment-water interface, an area with elevated microbial biomass (e.g. Rhoads et al. 1984, Novitsky \& Karl 1986).

\section{VLP controls and counting accuracy}

The mean of the control filters, $4.31 \times 10^{5} \mathrm{VLPs} \mathrm{ml}^{-1}$ $\left(\mathrm{SE}=7.0 \times 10^{4}\right)$, was 1.1 and $0.12 \%$ of the grand means of VLP counts in the water column and pore water, respectively. A running variance:running mean ratio was calculated to determine the number of microscopic fields necessary to estimate accurately the quantity of pore water VLPs on a filter (data not shown). The ratio stabilized after eight $100 \times 100 \mu \mathrm{m}$ fields were counted, with an average number of 33 VLPs per field. For all samples in this study, therefore, VLPs in 10 fields were counted on each filter.

\section{VLP extraction from pore water}

Mean efficiency of VLP extraction using coliphage T2 was $65.3 \%(\mathrm{SE}=2.9)$ (data not shown). VLP counts from field samples were not corrected to reflect this efficiency, however, because viruses used for the efficiency test were a monoculture of 1 size class $(70 \times$ $100 \mathrm{~nm}$ head diameter), and they did not reflect the size range of VLPs of natural seawater, typically 20 to $250 \mathrm{~nm}$ head diameter (Børsheim 1993, Fuhrman \& Suttle 1993, Proctor 1997), with smaller viruses most abundant (30 to $60 \mathrm{~nm}$, Bergh et al. 1989, Wommack et al. $1992_{;}<60 \mathrm{~nm}$, Bratbak et al. 1990, Cochlan et al. 1993).

\section{VLPs versus dissolved DNA}

There was no significant difference in the concentration of VLPs in DNase-treated pore-water samples and control samples ( $t$-test, $\mathrm{p}=0.16$; data not shown). The DNase assay showed degradation of DNA within $10 \mathrm{~min}$ and a change in absorbance of $0.0012 \mathrm{~min}^{-1}$ $\mathrm{ml}^{-1}$ of DNA substrate (data not shown).

\section{VLPs in the water column and pore water}

VLP concentrations were about 10 times higher in pore-water samples (grand mean $=3.57 \times 10^{8}$ VLPS $\mathrm{ml}^{-1}$ ) than in the water-column samples (grand mean $=$ 


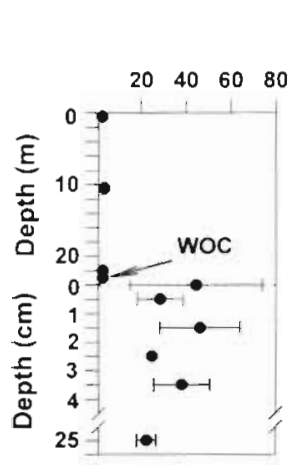

Sta. 1

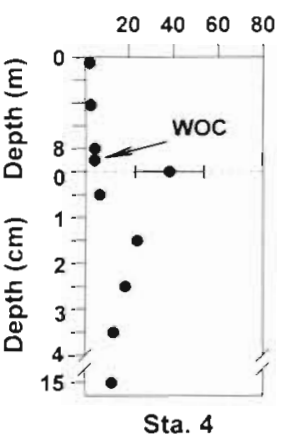

VLP $\mathrm{ml}^{-1} \times 10^{7}$

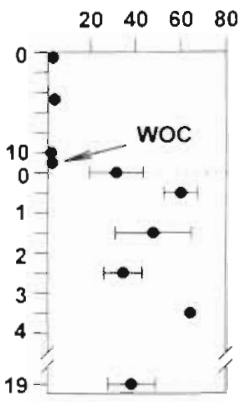

Sta. 2

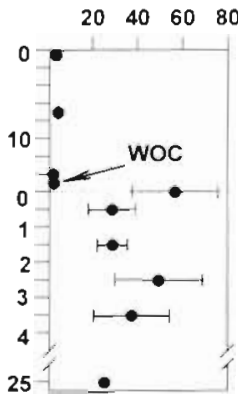

Sta. 3

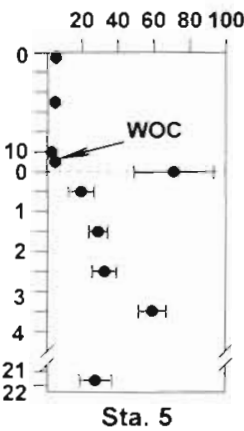

Fig. 3. Distribution of VLPs through the water column and into the sediment at Stns 1 to 5. Data are mean values ( $\mathrm{n}=2$ or 3 ) or single observations. Error bars $( \pm 1 \mathrm{SE})$ are used when $n=$ 3. WOC: water over box core; dashed line indicates the sediment-water interface

$3.83 \times 10^{7} \mathrm{VLP}_{\mathrm{S}} \mathrm{ml}^{-1}$ ) (Fig. 3) $(\mathrm{p}=0.0001$, Wilcoxon rank sum test). The grand means of the VLP concentrations in the water-column samples varied significantly among stations (range of the grand means $=3.03$ to $5.00 \times 10^{7}$ VLPs $\mathrm{ml}^{-1}$ ), increasing steadily from Stn 1

Table 1. Grand means ( $n=6$ to 18 ) of VLPs and bacteria in the water column (WC) and sediment (SED) at Stns 1 to 5. Superscripts represent results of a posteriori tests. Tukey's Studentized range (HSD) test was used for sediment data (sample sizes were unequal), Ryan-Einot-Gabriel-Welsch multiple $F$ test for water-column data (sample sizes were equal). Within a column, means with different letters are significantly different $(p<0.05)$

\begin{tabular}{|c|c|c|c|c|}
\hline \multirow[t]{2}{*}{ Stn } & \multicolumn{2}{|c|}{ VLP ml-1 $\times 10^{7}$} & \multicolumn{2}{|c|}{ Bacteria $\mathrm{ml}^{-1} \times 10^{6}$} \\
\hline & WC & SED & $W C^{a}$ & SED \\
\hline 1 & $3.03^{B}$ & $34.16^{\mathrm{AB}}$ & $2.34^{\mathrm{AB}}$ & $6.71^{\mathrm{A}}$ \\
\hline 2 & $3.25^{\mathrm{B}}$ & $44.43^{\mathrm{A}}$ & $2.13^{B}$ & $6.16^{\mathrm{A}}$ \\
\hline 3 & $3.63^{\mathrm{B}}$ & $38.46^{\mathrm{AB}}$ & $2.46^{\mathrm{AB}}$ & $5.93^{\mathrm{A}}$ \\
\hline 4 & $4.26^{\mathrm{AB}}$ & $21.69^{\mathrm{B}}$ & $2.49^{A B}$ & $7.34^{A}$ \\
\hline 5 & $5.00^{\mathrm{A}}$ & $39.57^{\mathrm{AB}}$ & $2.49^{A}$ & $6.47^{\mathrm{A}}$ \\
\hline
\end{tabular}

to Stn 5 (north to south) along the transect ( $p=0.037$, 1-way ANOVA on ranked data; Conover \& Iman 1981, Potvin \& Roff 1993) (Table 1). In contrast, VLP concentrations in the pore-water samples were more variable at each depth horizon and with depth in the sediment (Fig. 3). Although the grand means of the VLP concentrations were significantly different among stations (range of the grand means $=2.17$ to $4.44 \times 10^{8}$ VLPs $\mathrm{ml}^{-1}$ ), they did not exhibit the steady north to south increase seen in the water-column values $(p=0.0007$, 1-way ANOVA on ranked data) (Table 1). A consistent pattern among stations was a 7.3- to 18.7-fold increase in average VLP concentrations in sediment-waterinterface samples relative to WOC samples.

\section{Bacteria in the water column and pore water}

Bacteria concentrations were significantly higher in the pore-water samples (grand mean $=6.52 \times 10^{6}$ cells $\mathrm{ml}^{-1}$ ) than in the water-column samples (grand mean including and excluding WOC samples $=3.34 \times 10^{6}$ cells $\mathrm{ml}^{-1}$ and $2.38 \times 10^{6}$ cells $\mathrm{ml}^{-1}$, respectively) ( $\mathrm{n}=1$ to 3) (Fig. 4, Table 1) (including and excluding WOC samples, $p=0.0001$, Wilcoxon rank sum test). The means of the bacterial densities were similar throughout the water column (range of the grand means $=2.13$ to $2.49 \times 10^{6}$ cells $\mathrm{ml}^{-1}$, excluding WOC samples), but increased about 3 -fold in the water overlying the sediment in the box core. The increase in bacteria abundances in the WOC samples is likely due to a sampling artifact; see the argument in 'Hydrographic data' section. Differences among stations in water-column bacteria densities were significant, with highest values at the southernmost station, when WOC samples were excluded from the calculations ( $\mathrm{p}=0.038,1$-way ANOVA on ranked data) (Table 1). Within the porewater samples, mean bacterial concentrations were maximum at the sediment-water interface, decreased in the first $\mathrm{cm}$, and changed little $\left(4.27\right.$ to $5.81 \times 10^{6}$ cells $\mathrm{ml}^{-1}$ ) down to 15 to $25 \mathrm{~cm}$ depth (Fig. 4). Bacterial densities in the pore water did not vary significantly among stations (Table 1).

\section{Virus to bacteria ratio (VBR)}

The average VBR in the water column was similar among stations and ranged from 11.8 to 17.2 (Fig. 5). The lowest VBR at each station was in the WOC sample (Fig. 5), a result caused by the high bacterial counts in these samples (Fig. 4). Within pore-water samples, the average VBR was consistently higher and more variable than in water samples and ranged from 29.3 to 84.7 (Fig. 5). 


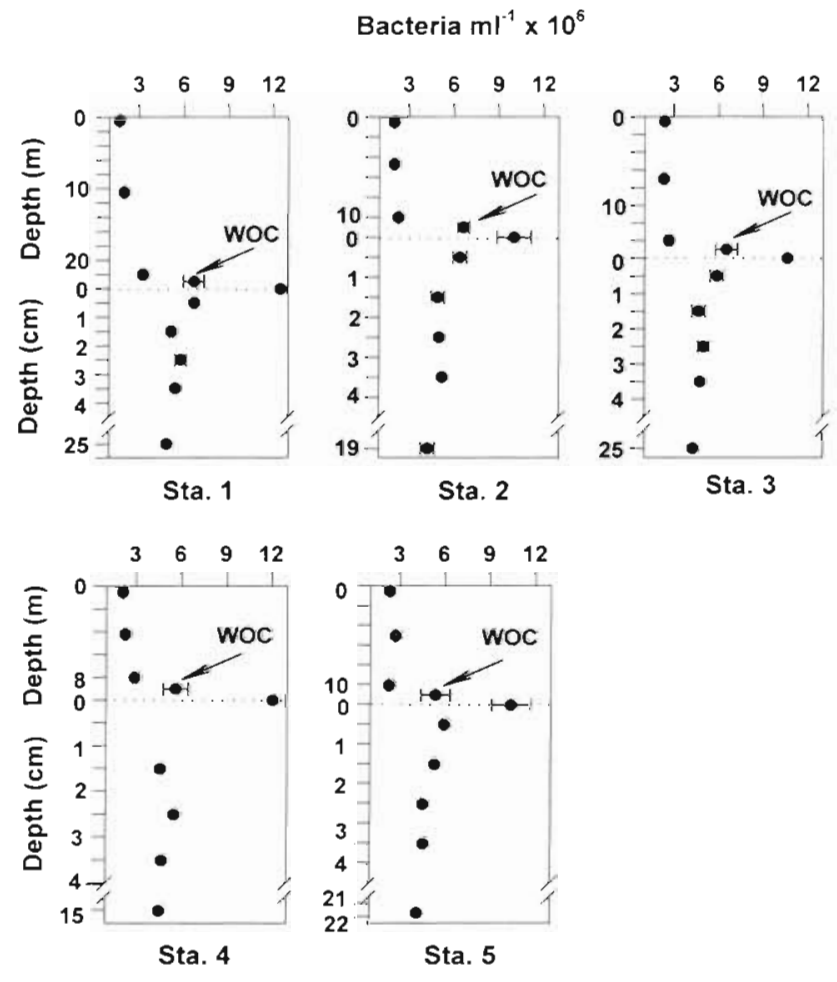

Fig. 4. Distribution of bacteria through the water column and into the sediment at Stns 1 to 5 . Data are mean values $(n=2$ or 3 ) or single observations. Error bars $( \pm 1 \mathrm{SE})$ are used when $n=3$. WOC: water over boxcore; dashed line indicates the sediment-water interface

\section{Sediment characteristics}

The sediments from each station consisted of very fine to medium sand, with mean particle size varying from 99 to $370 \mu \mathrm{m}$ and an average silt-clay percentage varying from 2.9 to $30.7 \%$ (Table 2). The average water content of the sediment ranged from 16.8 to $32.1 \%$ across stations (data not shown). The average combustible fraction of sediment from all stations ranged from 0.3 to $2.1 \%$ (data not shown). Percent water covaried positively with percent combustibles; otherwise, there were no trends among stations.

\section{Property-property plots}

There was a significant, positive correlation between VLPs and bacteria in the water-column samples when WOC data were excluded from the calculations (Spearman's coefficient, $r_{s}=0.31 ; p=0.04$ ) (Fig, 6a). No significant correlation was obtained, however, in a comparison of VLPs and bacterial abundances in samples from sediment pore water. Likewise, no correlation was apparent between VLPs and bacteria abundances in samples from water over the core. Note that
VBR
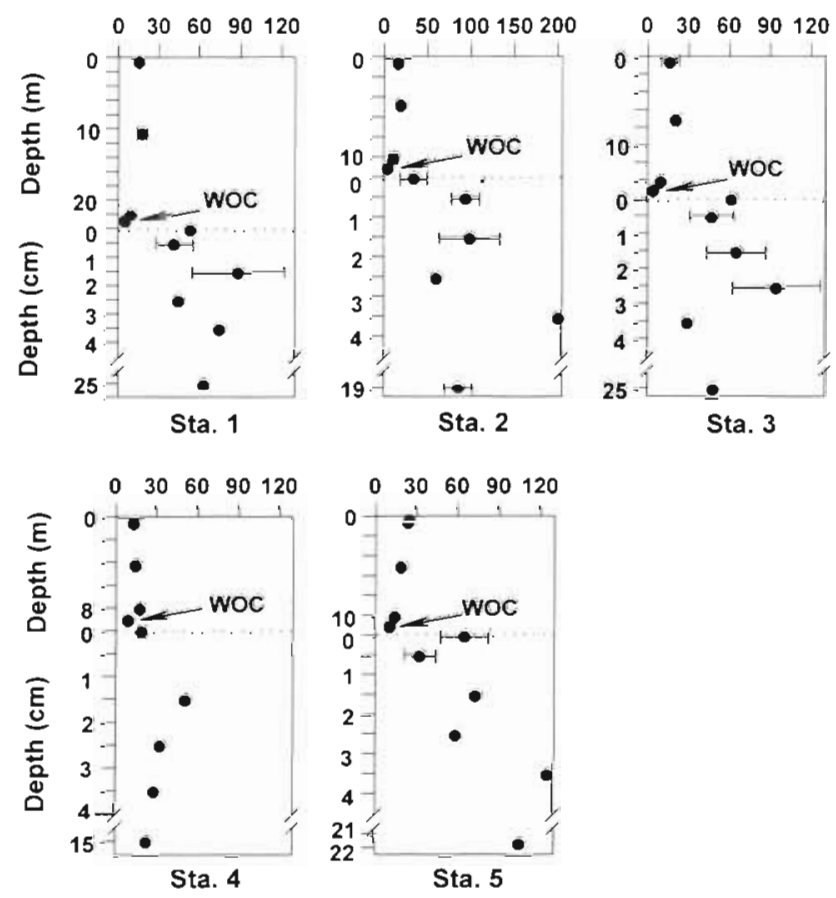

Fig. 5. Virus to bacteria ratio (VBR) through the water column and into the sediment at Stns 1 to 5 . Data are mean values $(\mathrm{n}=2$ or 3 ) or single observations. Error bars $( \pm 1 \mathrm{SE})$ are used when $n=3$. WOC: water over box core; dashed line indicates the sediment-water interface

VLP concentrations varied much less in the water column than in the pore water.

When only sediment samples were examined, there was a significant negative correlation between VLP counts and mean particle size (Spearman's coefficient, $r_{s}=-0.42, p=0.035$ ) (Fig , 6b). There were no significant correlations between VLP abundance and percent water content or percent combustibles (data not shown).

Table 2. Mean particle size and percent silt-clay in the uppermost and deepest sediment horizons at Stns 1 to 5. Daia are mean values $(\mathrm{n}=3$ ) with $\mathrm{SE}$ in parentheses

\begin{tabular}{|lrcr|}
\hline Stn & $\begin{array}{c}\text { Depth } \\
(\mathrm{cm})\end{array}$ & $\begin{array}{c}\text { Mean particle size } \\
(\mu \mathrm{m})\end{array}$ & $\%$ Silt-clay \\
\hline 1 & 0.5 & $302(74)$ & $6.4(2.6)$ \\
& 25.0 & $213(30)$ & $16.1(5.2)$ \\
2 & 0.5 & $145(2)$ & $6.8(0.2)$ \\
& 19.0 & $169(14)$ & $10.6(0.9)$ \\
3 & 0.5 & $160(27)$ & $12.5(4.6)$ \\
& 25.0 & $171(22)$ & $8.2(1.7)$ \\
4 & 0.5 & $370(36)$ & $2.9(0.2)$ \\
& 15.0 & $299(4)$ & $3.2(0.6)$ \\
5 & 0.5 & $205(35)$ & $5.2(2.5)$ \\
& 21.3 & $99(10)$ & $30.7(4.5)$ \\
\hline
\end{tabular}



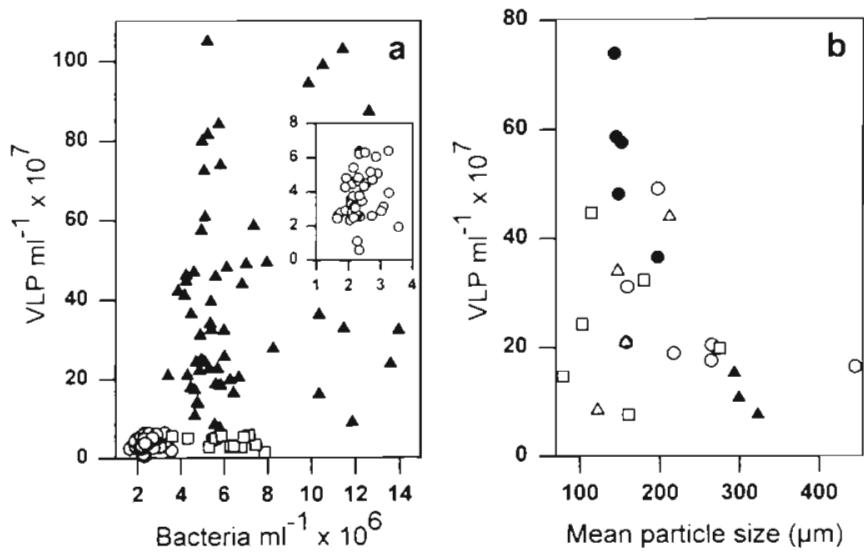

Fig. 6. Property-property plots. (a) VLPs vs bacteria and (b) VLPs in sediment pore water versus mean particle size. In (a), symbols are as follows: (o) water-column values excluding samples from the box core; ( $($ ) values from water over the box core; and (A) sediment pore water values. Inset in (a) is a plot of VLPS versus bacteria using only water-column values, excluding samples from the box core; units on inset axes are the same as those on larger graph. In (b), data from Stns 1 to 5 are represented by $0, \bullet, \Delta, \Delta$, and $\square$, respectively. (a) represents data from all 6 sediment horizons; (b) represents data from "only the uppermost and deepest horizons

\section{DISCUSSION}

Bacteria and VLPs at the mouth of the Chesapeake Bay were more abundant in pore water than in the overlying water column, a result anticipated from synthesis of ecological (Paul et al. 1993, Maranger \& Bird 1996, Steward et al. 1996) and public-health literature (e.g. Gerba et al. 1977, Smith et al. 1978, LaBelle et al. 1980). The present study confirms previous research and extends our knowledge of VLP distributions to deeper sediment horizons. Our study represents a first step to understanding the distribution of viruses in sub-surface sediments. Given the geographic breadth inherent in our sampling scheme, plus the number of parameters measured (VLPs, bacteria, grain size, etc.), we chose to quantify microbial constituents only in the pore water, not from the bulk sediment as well. In this discussion, we will compare our results with those of earlier studies, and consider how virus-bacteria interactions in the sediments may contrast with those in the water column.

\section{VLPs and bacteria in the water column}

Previous water-column studies have shown that increases in virus abundances are associated with the thermocline (Weinbauer et al. 1995), increases in bacterial abundance (Bird et al. 1993, Cochlan et al. 1993, Weinbauer \& Suttle 1997), the chl a maximum (Boeh- me et al. 1993) or proximity to surface (Hara et al. 1996) and coastal waters (Cochlan et al. 1993). In contrast, Wommack et al. (1992) found no difference in viral abundance between surface- and bottom-water samples in the mesohaline portion of Chesapeake Bay, even when the water column was stratified and bacteria were more abundant above the pycnocline than below it. In addition, they found no association between virus counts and sampling location. In the present work, VLP counts in the water column were not correlated with chl a values; however, there was a positive and significant correlation with bacteria abundance, and a significant difference with location across the Bay mouth.

\section{VLPs and bacteria in the sediment}

This first report of sub-surface distributions of VLPS demonstrates that viruses are numerically significant components of the microbial community not only at the sediment-water interface, but also to a depth of at least $25 \mathrm{~cm}$ in sediments from the lower Chesapeake Bay. Furthermore, VLP abundances varied inversely with sediment grain size at both surface and deep horizons. Estimates of VLPs in marine and freshwater sediments vary over 3 orders of magnitude, from $10^{7}$ to $10^{10} \mathrm{ml}^{-1}$, with the lowest estimates from pore water and the highest estimates from counts of viruses extracted from bulk sediments (Paul et al. 1993, Maranger \& Bird 1996, Steward et al. 1996, present study).

The large range of values likely arises, in part, from methodological differences (see below); however, differences among VLP estimates mostly depend on whether bulk sediment or pore water was analyzed. Although there has never been a side-by-side comparison of VLPs in bulk sediment and pore water, our data and limited reports in the literature suggest that VLP abundance is greater in bulk sediment than in pore water. The inventory of VLPs extracted from bulk sediment includes particle-adsorbed VLPs as well as VLPs in pore water. Therefore, it is not surprising that counts of VLPs extracted from bulk sediment can be orders of magnitude higher than counts from pore water alone. In the particle-rich environment of sediments, therefore, we hypothesize that most viruses will be adsorbed and only a small percentage of them will be found in the pore water.

The VBR in Chesapeake Bay pore water was greater than in the water column (ratios ranged from 29 to 85 and 12 to 17 , respectively). In the Chukchi Sea, the VBR in pore water (surface $1 \mathrm{~cm}$ ) also was higher than in surface water (ratios were 12.9 and approximately 4.0, respectively) (Steward et al. 1996). The trend of a higher VBR in pore water of marine sediments con- 
trasts with results from freshwater sediments, where the VBR is generally lower. In freshwater Lac Gilbert, Canada, with the exception of 1 sample, the VBR in surface sediments was lower than that in the water column (ratios were approximately 1.4 and 13.3, respectively) (Maranger \& Bird 1996). The comparatively high VBR determined in the present study may arise from methodological differences. We counted viruses using epifluorescence microscopy, a technique up to 7 times more efficient (Hennes \& Suttle 1995, Weinbauer \& Suttle 1997) than the transmission electron microscopy method used in the other studies (Maranger \& Bird 1996, Steward et al. 1996).

Acknowledgements. We are grateful to Captains Robert Bray and Donnie Padgett, R. C. Kidd, Kimani Kimbrough, John McLain, and Gail Bargerstock for their assistance in the field. We appreciate comments by William Dunstan, Darcy Lonsdale, Lita Proctor, Anthony Provenzano, $\mathrm{Jr}_{\mathrm{r}}$ and 3 anonymous reviewers on earlier versions of this manuscript. Old Dominion University provided ship time aboard the RV 'Linwood Holton'. We appreciate Thurman Gardner's efforts in designing and building the sediment sampling device. Thanks are due to Brian Weid and Rudy Zervigon for analyzing sediment and to Brian Parsons for producing the map.

\section{LITERATURE CITED}

Bergh $\varnothing$, Børsheim KY, Bratbak G, Heldal M (1989) High abundance of viruses found in aquatic environments. Nature 340:467-468

Bird DF, Maranger R, Karl DM (1993) Palmer LTER: aquatic virus abundances near the Antarctic Peninsula. Antarc $J$ US 28:234-235

Boehme J, Frischer ME, Jiang SC, Kellogg CA, Pichard S, Rose JB, Steinway C, Paul JH (1993) Viruses, bacterioplankton, and phytoplankton in the southeastern Gulf of Mexico: distribution and contribution to oceanic DNA pools. Mar Ecol Prog Ser 97:1-10

Børsheim KY (1993) Native marine bacteriophages. FEMS Microbiol Ecol 102:141-159

Bratbak G, Heldal M, Norland S, Thingstad TF (1990) Viruses as partners in spring bloom microbial trophodynamics Appl Environ Microbiol 56:1400-1405

Bratbak G. Heldal M. Thingstad TF, Riemann B, Haslund OH (1992) Incorporation of viruses into the budget of microbial C-transfer. A first approach. Mar Ecol Prog Ser 83 $27.3-280$

Cochlan WP, Wikner J, Steward GF, Smith DC, Azam F (1993) Spatial distribution of viruses, bacteria and chlorophyll a in neritic, oceanic and estuarine environments. Mar Ecol Prog Ser 92:77-87

Conover WJ, Iman RL (1981) Rank transformation as a bridge between parametric and non-parametric statistics. Am Stat 35:124-129

Drake LA, Choi KH, Haskell A, Dobbs FC (1997) Vertical profile of virus-like particles and bacteria in the water column and sediments of Chesapeake Bay. Abstract from Aquatic Sciences Meeting, Santa Fe, 10-14 February 1997. American Society for Limnology and Oceanography, Waco, TX, p 150

Folk RL (1980) Petrology of sedimentary rocks. Hemphill Publishing Company, Austin
Fuhrman JA (1992) Bacterioplankton roles in cycling of organic matter: the microbial food web. In: Falkowski PG, Woodhead AD (eds) Primary productivity and biogeochemical cycles in the sea. Plenum Press, New York, p 361-383

Fuhrman JA, Noble RT (1995) Viruses and protists cause similar bacterial mortality in coastal seawater. Limnol Oceanogr 40:1236-1242

Fuhrman JA, Suttle CA (1993) Viruses in marine planktonic systems. Oceanography 6:51-63

Gerba CP, Goyal SM, Smith EM, Melnick JL (1977) Distribution of viral and bacterial pathogens in a coastal canal community. Mar Pollut Bull 8:279-282

Hara S, Koike I, Terauchi K, Kamiya H, Tanoue E (1996) Abundance of viruses in deep oceanic waters. Mar Ecol Prog Ser 145:269-277

Hennes KP, Suttle CA (1995) Direct counts of viruses in natural waters and laboratory cultures by epifluorescence microscopy. Limnol Oceanogr 40:1050-1055

LaBelle RL, Gerba CP, Goyal SM, Melnick JL, Cech I, Bogdan GF (1980) Relationship between environmental factors, bacterial indicators, and the occurrence of enteric viruses in estuarine sediments. Appl Environ Microbiol 39: $588-596$

Maranger R, Bird DF (1996) High concentrations of viruses in the sediments of Lac Gilbert, Québec. Microb Ecol 31: $141-151$

Mathias CB, Kirschner AKT, Velimirov B (1995) Seasonal variations of virus abundance and viral control of the bacterial production in a backwater system of the Danube River. Appl Environ Microbiol 61:3734-3740

Middelboe M, Jorgensen NOG, Kroer N (1996) Effects of viruses on nutrient turnover and growth efficiency of noninfected marine bacterioplankton. Appl Environ Microbiol 62:1991-1997

Murray AG, Eldridge PM (1994) Marine viral ecology: incorporation of bacteriophage into the microbial planktonic food web paradigm. J Plankton Res 16:627-641

Novitsky JA, Karl DM (1986) Characterization of microbial activity in the surface layers of a coastal sub-tropical sediment. Mar Ecol Prog Ser 28:49-55

Parsons TR, Maita Y, Lalli CM (1992) A manual of chemical and biological methods for seawater analysis. Pergamon Press, Elmsford

Paul JH, Rose JB, Jiang SC, Kellogg CA, Dickson L (1993) Distribution of viral abundance in the reef environment of Key Largo, Florida. Appl Environ Microbiol 59:718-724

Porter KG, Feig Y (1980) The use of DAPI for identifying and counting aquatic microflora. Limnol Oceanogr 25:943-948

Potvin C. Roff D (1993) Distribution-free and robust statistical methods: viable alternatives to parametric statistics. Ecology $74: 1617-1628$

Proctor LM (1997) Advances in the study of marine viruses. Microsc Res Tech 37:136-161

Proctor LM, Fuhrman JA (1990) Viral mortality of marine bacteria and cyanobacteria. Nature 343:60-62

Proctor LM, Okubo A, Fuhrman JA (1993) Calibrating estimates of phage-induced mortality in manne bacteria: ultrastructural studies of marine bacteriophage development from one-step growth experments. Microb Ecol 25: $161-182$

Rhoads, DC, Boyer LF, Welsh BL, Hampson GR (1984) Seasonal dynamics of detritus in the benthic turbidity zone (BTZ); implications for bottom-rack molluscan mariculture. Bull Mar Sci 35:536-549

Rublee PA (1982) Seasonal distribution of bacteria in salt marsh sediments in North Carolina. Estuar Coast Shelf Sci $15: 67-74$ 
SAS (1996) SAS version 6.09. SAS Institute Inc, Cary, NC

Smith EM, Gerba CP, Melnick JL (1978) Role of sediment in the persistence of enteroviruses in the estuarine environment. Appl Environ Microbiol 35:685-689

Spencer R (1955) A marine bacteriophage. Nature 175: $690-691$

Steward GF, Smith DC, Azam F (1996) Abundance and production of bacteria and viruses in the Bering and Chukchi Seas. Mar Ecol Prog Ser 131:287-300

Suttle CA (1993) Enumeration and isolation of viruses. In: Kemp PF, Sherr B, Sherr E, Cole JJ (eds) Handbook of methods in aquatic microbial ecology. Lewis Publishers, Boca Raton, p 121-134

Suttle CA (1994) The significance of viruses to mortality in aquatic microbial communities. Microb Ecol 28:237-243

Torrella F, Morita RY (1979) Evidence by electron micrographs for a high incidence of bacteriophage particles in

Editorial responsibility: Gunnar Bratbak,

Bergen, Norway the waters of Yaquina Bay, Oregon: ecological and taxonomical implications. Appl Environ Microbiol 37: $774-778$

Valentine AF, Chen PK, Colwell RR, Chapman GB (1966) Structure of a marine bacteriophage as revealed by the negative-staining technique. J Bacteriol 91:819-822

Weinbauer MG, Fuks D, Puskaric S, Peduzzi P (1995) Diel, seasonal, and depth-related variability of viruses and dissolved DNA in the northern Adriatic Sea. Microb Ecol 30 : $25-41$

Weinbauer MG, Suttle CA (1997) Comparison of epifluorescence and transmission electron microscopy for counting viruses in natural marine waters. Aquat Microb Ecol 13: $225-232$

Wommack KE, Hill RT, Kessel M, Russek-Cohen E, Colwell RR (1992) Distribution of viruses in the Chesapeake Bay. Appl Environ Microbiol 58:2965-2970

Submitted: January 12, 1998; Accepted: May 25, 1998

Proofs received from author(s): September 23, 1998 